\title{
Prototipe Sistem Informasi Perpustakaan Pusat dan Daerah
}

\author{
Vieka Aprilya Intanny ${ }^{1}$, Paulus Insap Santosa ${ }^{2}$, Abdul Kadir ${ }^{3}$ \\ Jurusan Teknik Elektro dan Teknologi Informasi, Fakultas Teknik, Universitas Gadjah Mada \\ Jl. Grafika No.2 55281, D.I. Yogyakarta \\ E-mail: ${ }^{1}$ vieka.cio.8a@mail.ugm.ac.id, ${ }^{2}$ insap@jteti.gadjahmada.edu, ${ }^{3}$ akadir64@gmail.com
}

Masuk: 23 Januari 2015; Direvisi: 4 Februari 2015; Diterima: 5 Februari 2015

\begin{abstract}
Library has one of important resources to obtain information for research needs. The quality of a library information system needs to improve promptly because the information is needed quickly and accurately. In order to present library catalogue data that can be integrated with all central and local libraries, the library information system of Research and Development of the Human Resources Agency of the Ministry of Communication and Information Technology (Balitbang SDM Kominfo) needs to be well developed. The aim of this research is to design a prototype of library information system in order to present library data from central and local libraries accurately. Simulation tests are performed in eight research centers in the Ministry of Communication and Information Technology. The test is performed to analyze the perception of the users about the effectiveness of the system. The results show that the central library and information systems have good quality.
\end{abstract}

Keywords: central library, local library, prototype, information system

\begin{abstract}
Abstrak. Perpustakaan merupakan sarana untuk mendapatkan literasi informasi melalui hasil penelitian yang telah dilakukan. Peningkatan kualitas layanan sistem informasi perpustakaan yang tersaji dengan cepat, akurat dan aktual mutlak diperlukan. Untuk itu dipandang perlu suatu perbaikan sistem perpustakaan Balitbang SDM Kominfo agar dapat menyajikan data perpustakaan yang dapat terintegrasi antara perpustakaan pusat dan perpustakaan daerah. Penelitian ini bertujuan untuk merancang prototipe suatu sistem informasi perpustakaan pusat dan daerah agar data perpustakaan pusat dan daerah dapat tersaji dengan cepat dan akurat. Pengujian dilakukan dengan simulasi sistem di delapan balai Kominfo. Pengujian ini bertujuan untuk menganalisis persepsi administrator pusat dan administrator daerah mengenai efektivitas sistem. Hasil pengujian menunjukkan bahwa sistem informasi perpustakaan pusat dan daerah memiliki kualitas yang baik.
\end{abstract}

Kata Kunci: perpustakaan daerah, perpustakaan pusat, prototipe, sistem informasi

\section{Pendahuluan}

Teknologi Informasi dan Komunikasi (TIK) memiliki peran penting dalam pertumbuhan ekonomi suatu bangsa (Ramli, dkk., 2013). Inovasi dalam bidang TIK semakin berkembang seiring dengan meningkatnya kebutuhan akan literasi informasi di masyarakat. Hal ini senada dengan peran perpustakaan nasional Republik Indonesia dalam pengembangan literasi informasi sebagai amanat konstitusi (Dwiyanto, 2007:1). Salah satu sarana untuk mendukung terciptanya literasi informasi di masyarakat adalah dengan adanya perpustakaan. Perpustakaan merupakan salah satu institusi yang bergerak di bidang pengelolaan informasi yang sangat memerlukan teknologi informasi (Suhartika, 2004:1)

Perpustakaan diharapkan mampu menyediakan sarana dan prasarana sesuai dengan standar nasional perpustakaan yang dikembangkan sesuai dengan kemajuan TIK (Dwiyanto, 2007:9). Oleh karena itu, perkembangan TIK pada lingkup perpustakaan ditandai dengan munculnya sistem informasi untuk perpustakaan. Aplikasi perangkat lunak memiliki peran penting dalam mengatur alur kerja dalam perpustakaan (Naji \& Liu, 2010:1). Implementasi perangkat lunak dalam perpustakaan akan memudahkan dalam pengelolaan data dan meningkatkan efektifitas. 
Perkembangan TIK dalam bidang perpustakaan juga terjadi di perpustakaan Badan Literasi dan Pengembangan Sumber Daya Manusia Kementerian Komunikasi dan Informatika (Balitbang SDM Kominfo). Perpustakaan Balitbang SDM Kominfo merupakan sarana bagi para pegawai Kominfo untuk mendapatkan literasi informasi melalui koleksi buku yang dimiliki perpustakaan Balitbang SDM Kominfo. Untuk dapat semakin meningkatkan kepuasan pengguna perpustakaan akan kemudahan informasi mengenai katalog buku yang ada di perpustakaan Balitbang SDM Kominfo, maka dibuatlah suatu sistem informasi perpustakaan Balitbang SDM Kominfo berbasis web. Perkembangan TIK tidak hanya berdampak pada pengelolaan data buku yang handal, tetapi juga dapat meningkatkan kualitas pelayanan kepada anggota sehingga anggota dapat dengan mudah menemukan data buku yang diinginkan (Mei \& Guang-Quan, 2007:225)

Website perpustakaan Balitbang SDM Kominfo dapat diakses melalui alamat www.balitbang.kominfo.go.id. Website perpustakaan Balitbang SDM Kominfo berisi data buku, prosiding, jurnal, bunga rampai, hasil penelitian dan lain-lain. Data-data yang ada di perpustakaan Balitbang SDM Kominfo berasal dari data pengadaan buku yang ada di perpustakaan pusat. Untuk data buku dan hasil-hasil penelitian yang berasal dari daerah, prosesnya adalah input manual berdasarkan pengiriman buku dari daerah. Setiap buku dan hasil penelitian yang dikirim dari balai penelitian daerah akan di data kemudian diinputkan secara manual ke database website perpustakaan Balitbang SDM Kominfo. Data-data buku dan hasil penelitian yang sudah di-input melalui sistem otomatis akan tersimpan di database perpustakaan Balitbang SDM saja.

Hal yang sama juga dilakukan oleh balai penelitian yang ada di daerah. Masing-masing balai penelitian sudah memiliki website yang digunakan sebagai sarana untuk mempublikasikan hasil-hasil penelitian pada masing-masing balai. Namun, database yang ada di balai penelitian daerah dan database perpustakaan Balitbang SDM belum terintegrasi satu sama lain sehingga proses input data-data buku dan hasil penelitian dilakukan oleh masing-masing administrator di perpustakaan Balitbang SDM Kominfo dan di website balai penelitian daerah. Hal ini menyebabkan adanya duplikasi data antara perpustakaan Balitbang SDM Kominfo dengan website balai penelitian daerah karena masing-masing sistem melakukan pengelolaan data buku dan hasil-hasil penelitian. Pada sistem informasi daerah pengelolaan hasil-hasil penelitian selalu ter-update dengan cepat karena data hasil penelitian didapat secara up to date. Pengelolaan hasil penelitian di pusat dilakukan jika sudah mendapat kiriman data hasil penelitian dari daerah. Proses pengelolaan database yang terjadi pada masing-masing sistem berjalan sendiri-sendiri karena belum ada integrasi sistem antara perpustakaan Balitbang SDM dengan website balai penelitian daerah. Hal ini dirasa kurang efektif terutama dilihat dari segi waktu. Salah satu ciri sistem informasi yang baik adalah penyampaian informasi yang cepat dan akurat. Oleh karena itu diperlukan suatu perbaikan sistem di perpustakaan Balitbang SDM Kominfo agar data-data buku khususnya data hasil penelitian dapat tersaji dengan cepat dan akurat.

Berbagai kegiatan telah dilakukan untuk dapat meningkatkan mutu layanan perpustakaan antara lain pengelolaan koleksi, pengolahan data perpustakaan, seleksi dan akuisisi, sistem sirkulasi dan informasi serta kajian pemakai disamping katalog berbasis web, penelusuran bahan pustaka (OPAC) statistik dan sebagainya (Suhartika, 2004:3). Sebagai upaya untuk meningkatkan kualitas layanan perpustakaan maka diperlukan suatu sistem informasi perpustakaan yang akurat dan aktual dalam rangka mewujudkan literasi informasi kepada masyarakat. Berdasarkan kondisi yang ada pada perpustakaan pusat dan website balai daerah, saat ini data perpustakaan yang tersedia belum bisa diakses secara terintegrasi. Administrator balai daerah belum dapat mengakses sistem informasi perpustakaan pusat. Administrator daerah tidak memiliki hak akses untuk melakukan input data perpustakaan, semua proses input data dilakukan oleh administrator pusat. Oleh karena itu dibutuhkan pengintegrasian sistem informasi perpustakaan pusat yang akan memudahkan pustakawan dalam proses pencarian katalog.

Dalam penelitian ini, kendala tersebut diatasi dengan merancang suatu aplikasi perpustakaan yang dapat diakses oleh dua pengguna, yaitu pengguna dari pusat dan dari balai 
daerah. Masing-masing pengguna memiliki hak akses masing-masing. Administrator daerah memiliki hak akses untuk melakukan input data buku ke sistem perpustakaan sehingga aktifitas sistem dapat diakses oleh administrator daerah secara terintegrasi.

Berdasarkan uraian latar belakang di atas, maka dapat dirumuskan pokok permasalahan dalam penelitian yaitu belum adanya sistem informasi perpustakaan yang dapat menampung data buku perpustakaan pusat dan daerah serta dapat digunakan secara bersama-sama baik oleh administrator perpustakaan pusat maupun perpustakaan daerah. Berdasarkan latar belakang masalah yang dihadapi, dapat dirangkum tujuan dari penelitian yang dilakukan adalah untuk merancang suatu sistem informasi perpustakaan pusat dan daerah di Balitbang SDM Kominfo.

Hasil dari penelitian ini diharapkan mampu memberikan manfaat bagi perpustakaan pusat dan daerah, antara lain: (1) Dapat mempersingkat waktu memasukkan data buku perpustakaan karena proses input data dilakukan langsung oleh administrator daerah. (2) Data buku perpustakaan dapat diakses secara terintegrasi oleh pengguna perpustakaan Balitbang SDM Kominfo. (3) Dapat memberikan solusi bagi pengguna perpustakaan Balitbang SDM Kominfo dalam pencarian data buku yang ada di perpustakaan Balitbang SDM Kominfo.

\section{Tinjauan Pustaka \\ 2.1. Kajian Literatur}

Penelitian sebelumnya yang berhubungan dengan penelitian ini antara lain sebagai berikut. Pertama, penelitian oleh $\mathrm{Li}$, dkk (2012) yang bertujuan untuk mengatasi permasalahan pada manajemen sistem perpustakaan yang masih dilakukan secara manual. Perlu dibuat suatu sistem informasi yang dapat mengoptimalkan kinerja basis data yang direpresentasikan dalam bentuk aplikasi berbasis web service. Bagian terpenting dalam fase analisis kebutuhan sistem adalah perancangan use case diagram. Use case diagram lebih menekankan pada proses untuk mencapai output yang diinginkan oleh user (Li, dkk, 2012:433). Sistem yang dirancang memiliki beberapa fungsi yaitu, menambah, mengubah menghapus data buku dan data anggota, mengatur hak akses pada masing-masing user, melakukan peminjaman dan pengembalian buku, membayar denda, dan mengubah password untuk masing-masing user.

Kedua, penelitian oleh Naji dan Liu (2010). Di era yang semakin modern ini, penggunaan sistem informasi mutlak diperlukan untuk mencegah adanya redundansi data perpustakaan (Naji \& Liu, 2010:1). Untuk mengatasi permasalahan ini diperkenalkan penggunaan sistem informasi perpustakaan berbasis tiga lapis arsitektur. Model ini terdiri dari Presentation Layer, Business Logic Layer dan Data Access Layer. Dalam model ini, pengkodean dilakukan secara terpisah karena dapat mengurangi kesalahan pada sistem, dan dapat meningkatkan kinerja serta membantu perawatan sistem (Naji \& Liu, 2010:1).

Ketiga, penelitian oleh Yanqing dan Yongming (2010). Penelitian ini lebih menekankan pada pembuatan sistem informasi perpustakaan yang digunakan sebagai sumber referensi yang dapat digunakan bersama-sama dalam suatu universitas. Terdapat empat pengguna dalam perancangan sistem ini yaitu, sistem administrator, administrator perpustakaan, dosen dan mahasiswa. Masing-masing user memiliki hak akses yang berbeda-beda. Keuntungan yang didapat dalam implementasi sistem ini adalah aplikasi ini mudah untuk diinstall, dan dapat digunakan pada platform yang berbeda-beda (Yanqing \& Yongming, 2010:491).

Keempat, penelitian oleh Cheah, dkk, 1993. Penelitian ini mengembangkan implementasi application layer pada OSI arsitektur dengan menggunakan ISO Development Environment (ISODE) berdasarkan Manufacturing Message Spesification (MMS). Implementasi yang digunakan dalam penelitian adalah membagi application layer dalam OSI menjadi application protocol, application service dan application entity dengan menggunakan ISODE (Cheah, dkk, 1993:32).

\subsection{Landasan Teori}

Open System Interconnection (OSI) adalah sebuah internasional standar untuk memfasilitasi komunikasi antara komputer dengan spesifikasi dan teknologi yang berbeda (Cheah, 1993). Model abstrak ini direpresentasikan dalam bentuk layer sebagai interpreter dan 
standarisasi komunikasi komputer yang terhubung jaringan. Setiap layer memiliki fungsi khusus pada servis dan protokolnya. OSI terdiri dari tujuh layer (lapisan) yang mendefinisikan fungsi (Cheah, 1993). Untuk tiap layer-nya dapat terdiri dari sejumlah protokol yang berbeda, masingmasing menyediakan pelayanan yang sesuai dengan fungsi layer tersebut. Tujuan utama penggunaan model OSI adalah untuk membantu desainer jaringan memahami fungsi dari tiaptiap layer yang berhubungan dengan aliran komunikasi data, termasuk jenis-jenis protokol jaringan dan metode transmisi (Supandi, 2012). Model dibagi menjadi tujuh layer, dengan karakteristik dan fungsinya masing-masing. Tiap layer harus dapat berkomunikasi dengan layer di atasnya maupun di bawahnya secara langsung melalui serentetan protokol dan standard (Zimmermann, 1980:430).

Layer (1) Application Layer, berfungsi sebagai antarmuka dengan aplikasi dengan fungsionalitas jaringan, mengatur bagaimana aplikasi dapat mengakses jaringan, dan kemudian membuat pesan-pesan kesalahan. (2) Presentation Layer, berfungsi untuk mentranslasikan data yang hendak ditransmisikan oleh aplikasi ke dalam format yang dapat ditransmisikan melalui jaringan. (3) Session Layer, berfungsi untuk mendefinisikan bagaimana koneksi dapat dibuat, dipelihara, atau dihancurkan. (4) Transport Layer, berfungsi untuk memecah data ke dalam paket-paket data serta memberikan nomor urut ke paket-paket tersebut sehingga dapat disusun kembali pada sisi tujuan setelah diterima. (5) Network Layer, berfungsi untuk mendefinisikan alamat-alamat IP, membuat header untuk paket-paket, dan kemudian melakukan routing melalui internetworking dengan menggunakan router dan switch layer-3. (6) Data Link Layer, berfungsi untuk menentukan bagaimana bit-bit data dikelompokkan menjadi format yang disebut sebagai frame. (7) Physical Layer, berfungsi untuk mendefinisikan media transmisi jaringan, metode pensinyalan, sinkronisasi bit, arsitektur jaringan (seperti halnya Ethernet atau Token Ring), topologi jaringan dan pengabelan.

Dalam penelitian yang dilakukan oleh Naji (Naji \& Liu, 2010:3), perancangan arsitektur sistem informasi perpustakaan dilakukan dengan menggunakan tiga lapisan arsitektur yang terdiri dari Presentation Layer, Business Logic Layer dan Data Access Layer. (1) Presentation Layer. Dalam sistem ini, presentation layer bertugas untuk menampilkan dan memasukkan data dari dan ke business logic layer kepada pengguna sistem. Lapisan ini terdiri dari komponen yang digunakan untuk menampilkan antarmuka sistem dan mengatur interaksi dengan pengguna. (2) Business Logic Layer. Business Logic Layer bertanggung jawab terhadap logika bisnis dalam sistem informasi perpustakaan. Business logic layer terletak diantara presentation layer dan data access layer. Data yang ditangani oleh business logic layer hanya dapat berasal dari presentation layer dan data access layer. Business logic layer akan mengirim permintaan yang datang dari presentation layer ke data access layer. (3) Data Access Layer. Pada layer ini terdapat beberapa class yang berhubungan dengan berbagai layanan. Selain itu juga terdapat class dbhelper yang terdiri dari variabel koneksi yang berhubungan dengan basis data.

Banyak penelitian yang telah dilakukan untuk mengidentifikasi faktor-faktor yang menyebabkan kesuksesan sistem informasi. Salah satunya adalah penelitian yang dilakukan oleh DeLone dan McLean yang menyebutkan bahwa kesuksesan sebuah sistem informasi dapat direpresentasikan oleh system quality, information quality, use, user satisfaction, individual impact, dan organizational impact (DeLone, 2013). Pembuatan dari model ini dipicu oleh suatu proses pembuatan informasi dan dampak dari pengguna sistem informasinya. Ukuran yang dipakai oleh Delone dan McLean untuk mengukur system quality adalah kemudahan dalam penggunaan, fungsional, reliabilitas, fleksibilitas, kualitas data, integrasi dan kepentingan.

Dalam pembangunan perangkat lunak perpustakaan pusat dan daerah digunakan Unified Modeling Language (UML). UML pertama kali dikenalkan oleh Gray Booch, Jim Rumbaugh dan Ivar Jacobson (Chen, 2011). UML digunakan untuk mem-visualisasikan, mendefinisikan, membangun dan membuat dokumen dari arsitektur perangkat lunak. Dengan menggunakan UML dapat dibuat model untuk semua jenis aplikasi piranti lunak, dimana aplikasi tersebut dapat berjalan pada piranti keras, sistem operasi dan jaringan apapun, serta ditulis dalam bahasa pemrograman apapun. 


\section{Metode Penelitian}

\subsection{Model Penelitian}

Dalam penelitian perancangan prototype sistem informasi perpustakaan pusat dan daerah ini, dilakukan pengembangan dari segi lapisan arsitektur. Penambahan satu lapisan yaitu communication layer dalam arsitektur ini diharapkan dapat menambah performa dari sistem informasi yang dibangun. Arsitektur empat layer yang digunakan pada penelitian ini dapat dilihat pada Gambar 1.

Communication layer terletak diantara business layer dan data access layer. Communication layer bertanggung jawab terhadap pembagian access right, dimana dalam sistem ini terdapat beberapa pengguna yang memiliki hak akses yang berbeda-beda. Pengguna yang terdapat dalam sistem ini adalah administrator pusat, administrator daerah dan anggota perpustakaan. Ketika pengguna mengakses halaman website, maka pengguna berada di level presentation layer. Ketika pengguna memilih menu yang disediakan oleh sistem, maka sistem akan meminta pengguna untuk melakukan sistem login. Pengguna melakukan input data dan selanjutnya akan dilakukan validasi ke sistem dan database. Dalam hal ini dibutuhkan peran dari business logic layer dan data access layer. Setelah dilakukan pengecekan maka akan masuk kedalam tahap communication layer dimana pada tahap ini sistem akan mengecek hak akses dari pengguna yang dimasukkan ke dalam sistem. Pengecekkan ini dilakukan dengan melihat level pada masing-masing pengguna apakah masuk ke dalam level administrator pusat atau administrator daerah.

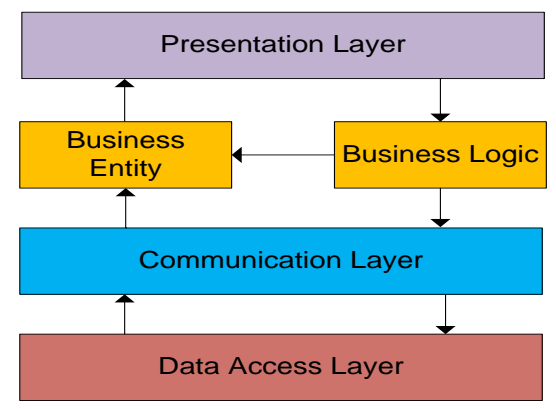

Gambar 1. Model Empat Lapisan Layer

\subsection{Jalan Penelitian}

Pada tahap pertama dilakukan pengumpulan data. Proses pengumpulan data dilakukan dengan melalui pengamatan pada website perpustakaan pusat website balai daerah. Pengumpulan data juga dilakukan dengan diskusi bersama administrator web perpustakaan pusat mengenai desain website perpustakaan dan format basis data yang digunakan.

Dari hasil pengumpulan data, tahapan berikutnya adalah perumusan masalah yang sering ditemui oleh administrator perpustakaan pusat adalah dalam proses input data buku perpustakaan. Dalam hal ini, administrator pusat dalam melakukan pengelolaan data buku baru dari daerah harus menunggu buku fisik terkirim dahulu ke perpustakaan pusat baru setelah itu dilakukan proses input data. Hal ini dirasa kurang efektif terutama dalam hal waktu. Jika admin perpustakaan daerah memiliki hak akses untuk meng-input data perpustakaan maka data-data buku perpustakaan pusat akan lebih cepat ter-update. Oleh karena itu dibutuhkan suatu sistem informasi yang dapat mengakomodasi kebutuhan-kebutuhan tersebut.

Untuk mengatasi permasalahan tersebut, dibuatlah suatu aplikasi perpustakaan yang dapat dikelola dengan menggunakan dua jenis pengguna. Pengguna pertama yaitu administrator pusat yang merupakan administrator utama dari sistem informasi perpustakaan pusat dan daerah. Administrator pusat adalah administrator perpustakaan yang ada pada perpustakaan pusat Balitbang SDM Kominfo. Administrator pusat memiliki tugas untuk mengelola data perpustakaan meliputi data buku, data administrator, data anggota, transaksi peminjaman dan pengembalian, dan pencarian data buku. Pengguna yang kedua adalah administrator daerah yang merupakan administrator dari sistem informasi perpustakaan balai daerah. Calon pengguna 
dari balai daerah adalah pustakawan pada masing-masing balai. Administrator daerah memiliki hak akses untuk melakukan pengelolaan buku yaitu hanya pada fungsi penambahan data buku dan pencarian data buku. Administrator daerah hanya dapat melakukan penambahan data buku yang ada di balai daerah ke sistem. Sedangkan untuk perubahan dan penghapusan data hanya dapat dilakukan oleh administrator pusat. Hal ini tentu lebih efektif untuk dapat mengatasi permasalahan dalam pengelolaan data buku terutama data buku dari balai daerah. Dengan adanya hak akses yang dimiliki oleh administrator daerah maka data buku dari daerah akan lebih cepat tersimpan dalam sistem dan dapat ditampilkan dengan lebih cepat dan akurat.

Tahap ketiga adalah studi pustaka, yang dilakukan dengan mempelajari penelitian sejenis berupa tesis, skripsi, jurnal dan paper untuk mendapatkan gambaran penelitian. Studi pustaka juga berguna untuk memperoleh solusi yang tepat dari permasalahan yang telah dirumuskan, yaitu layanan TIK seperti apa yang akan digunakan pada penelitian untuk mengatasi masalah sinkronisasi data perpustakaan pusat dan daerah. Tahap keempat adalah perancangan prototype sistem informasi. Tahapan perancangan dimulai dengan melakukan identifikasi seluruh pengguna yang terlibat dalam arsitektur sistem informasi. Arsitektur sistem informasi pada prototype sistem informasi perpustakaan dan daerah seperti yang digambarkan pada Gambar 2. Server terletak di perpustakaan pusat, sedangkan untuk client terdapat di delapan balai daerah.

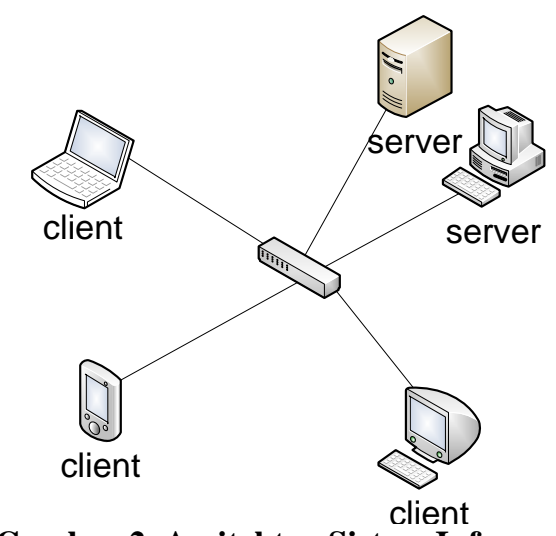

Gambar 2. Arsitektur Sistem Informasi

Tahap kelima adalah implementasi, dimana dibuat prototype berdasarkan analisis dan desain sistem yang telah dibuat melalui keempat tahapan sebelumnya. Tahap terakhir adalah pengujian dan penyempurnaan prototype. Tahapan pengujian dilakukan dengan menguji prototype yang telah dibuat. Penelitian ini memiliki lingkup nasional, dalam artian bahwa penelitian ini melibatkan delapan balai SDM Kominfo yang tersebar di delapan kota di Indonesia. Pengujian sistem dilakukan untuk mengetahui kesalahan program yang tidak sesuai dengan output yang diharapkan dan mengetahui kelemahan prototype sebagai batasan penelitian yang dapat disempurnakan pada saat penerapan secara riil di lapangan.

\section{Hasil Penelitian dan Pembahasan}

\subsection{Use Case Diagram}

Untuk merancang use case diagram, terlebih dahulu dilakukan identifikasi terhadap aktor atau pengguna sistem informasi yang meliputi administrator pusat, administrator daerah, dan anggota. Gambar 3 menggambarkan identifikasi pengguna dan hak akses yang dimiliki. (1) Administrator pusat merupakan pengguna sistem dengan hak akses yang paling tinggi. Administrator pusat memiliki hak untuk melakukan secara penuh pengelolaan data-data buku perpustakaan, mengelola data administrator dan data anggota perpustakaan. Administrator pusat berhak untuk mengelola proses peminjaman dan pengembalian buku perpustakaan. (2) Administrator daerah memiliki hak akses di bawah administrator pusat. Administrator daerah merupakan administrator dari sistem informasi perpustakaan yang berada di delapan balai 
Kominfo. Administrator daerah hanya memiliki hak untuk melakukan penambahan buku ke dalam sistem. Administrator daerah tidak berhak untuk melakukan pengubahan dan menghapus data-data perpustakaan. (3) Anggota merupakan pengguna sistem yang hanya memiliki hak untuk mencari dan melihat data-data buku perpustakaan.

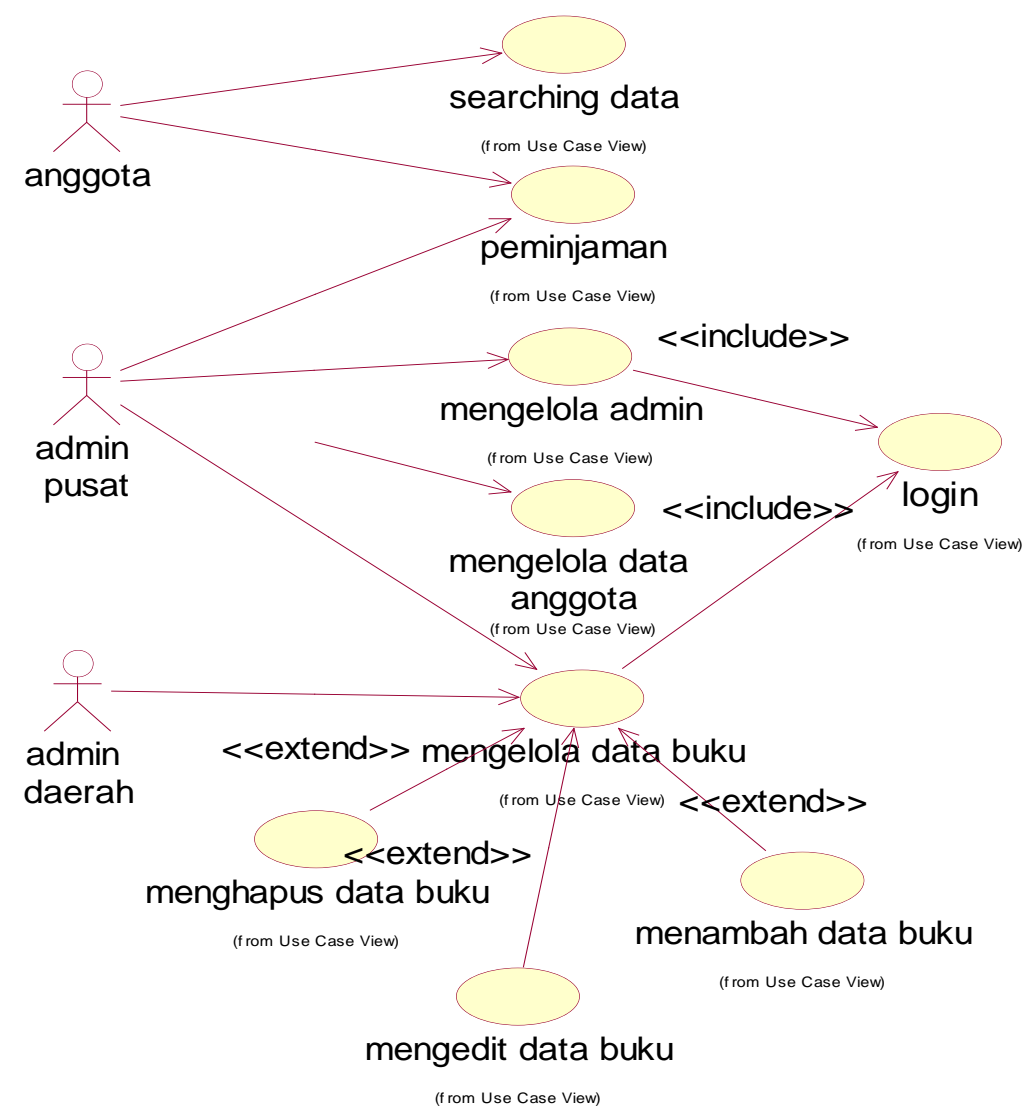

Gambar 3. Use Case Diagram

\subsection{Class Diagram}

Class diagram menggambarkan interaksi antar class serta atribut-atribut yang melekat pada class tersebut. Seluruh pengguna sistem informasi perpustakaan terdiri dari administrator pusat, administrator daerah dan anggota dapat mengakses data buku perpustakaan. Pada Gambar 4 ditampilkan class-class yang digunakan dalam perancangan sistem informasi pusat dan daerah. Terdapat empat class yang digunakan yaitu user, bibliography, anggota, dan transaksi. Masing-masing class memiliki atribut dan relasi antar class.

\subsection{Rancangan Antarmuka}

Antarmuka merupakan bagian terpenting bagi pengguna sistem informasi untuk berinteraksi dengan sistem. Pengguna sistem informasi yang berinteraksi langsung dengan sistem informasi perpustakaan pusat dan daerah ada tiga jenis yaitu administrator pusat, administrator daerah dan anggota. Antarmuka administrator pusat dan administrator daerah dirancang paling awal karena menu yang disajikan untuk pengguna ini adalah yang paling lengkap. Antarmuka anggota dirancang dengan menggunakan batasan dari beberapa fungsi menu dalam antarmuka administrator pusat dan administrator daerah. Secara umum, antarmuka dirancang sedemikian rupa sehingga hanya pada bagian isi web saja yang berubah secara dinamis tergantung dari menu yang dipilih oleh pengguna. Sementara header dan menu SI Perpustakaan dirancang untuk selalu tampil di setiap event menu. Rancangan antarmuka dibuat dengan memperhatikan aspek kemudahan penggunaan sistem yang merupakan salah satu dari aspek kesuksesan suatu sistem informasi (DeLone, 2013). 


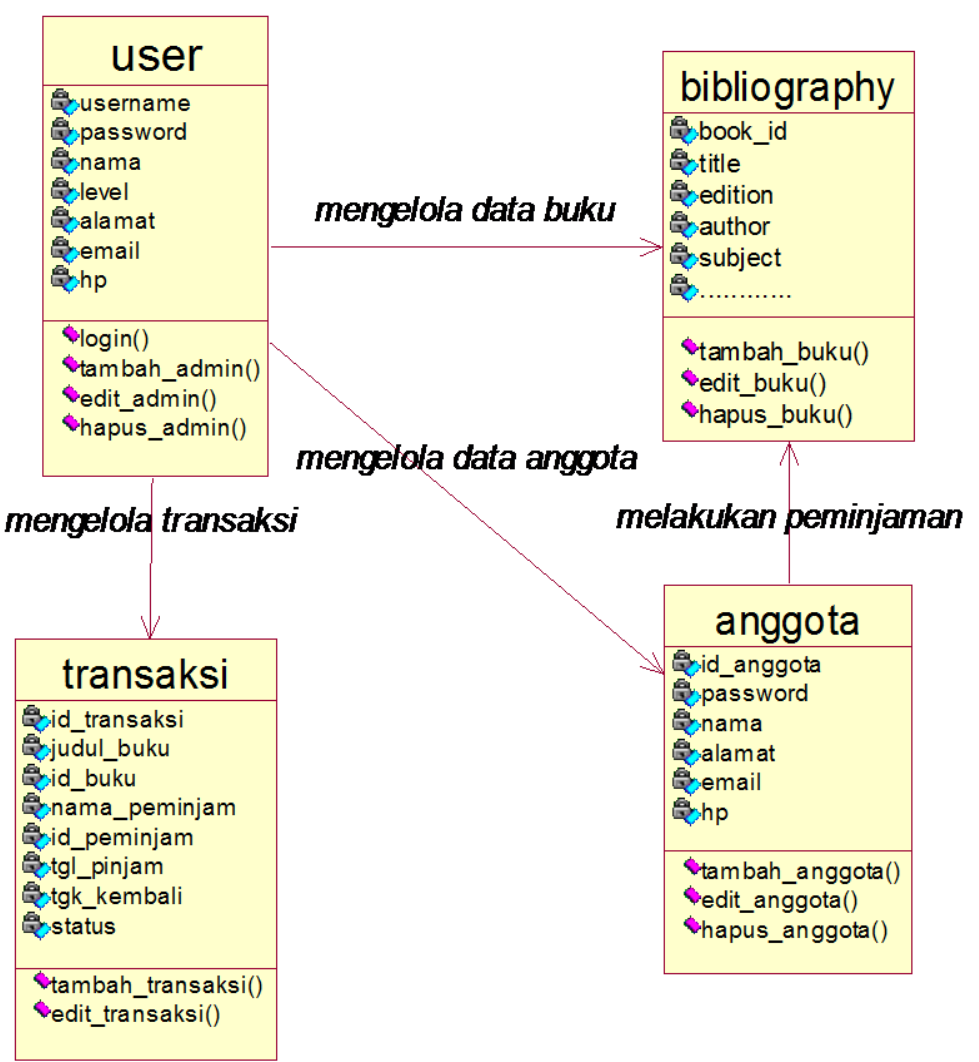

Gambar 4. Class Diagram

\subsection{Rancangan Menu}

Rancangan menu yang berhubungan dengan pemrosesan data buku terdiri atas: (1) Home, menampilkan halaman singkat tentang tujuan dibangunnya sistem informasi. (2) Data Administrator, menampilkan data administrator pengelola sistem informasi perpustakaan pusat dan daerah. Halaman ini menampilkan tabel user. (3) Data anggota perpustakaan, menampilkan data aggota perpustakaan yang sudah melakukan registrasi ke sistem. Terhubung dengan tabel anggota. (4) Transaksi, halaman ini menampilkan data transaksi peminjaman dan pengembalian. (5) Data buku, terhubung langsung ke tabel bibliography sehingga dapat menampilkan data lengkap buku di perpustakaan Balitbang SDM Kominfo. (6) Cari Buku, menampilkan halaman untuk proses pencarian data buku perpustakaan. (7) About, menampilkan informasi mengenai versi sistem informasi.

\subsection{Implementasi Sistem}

Implementasi sistem informasi perpustakaan pusat dan daerah ini dilakukan menggunakan bahasa pemrograman PHP dengan basis data yang digunakan adalah MySQL. Aplikasi PHP tersebut dapat dijalankan pada berbagai platform sistem operasi dan perangkat keras, tetapi implementasi dan pengujian sepenuhnya hanya dilakukan pada perangkat keras PC (Personal Computer) dengan sistem operasi Microsoft Windows XP.

Halaman Awal sistem informasi perpustakaan pusat dan daerah memiliki beberapa menu, yaitu Beranda, Administrator Pusat, Administrator Daerah, dan About. Untuk menu administrator pusat terdiri dari Home, Data Administrator, Data Anggota, Transaksi, Data Buku, Cari Buku, dan About. Sesuai dengan arsitektur yang dikembangkan dalam penelitian ini, maka pada tahap ini masuk ke dalam lapisan presentation layer. Tahap ini merupakan tahap ketika sistem menampilkan antarmuka ke aktor.

Halaman login dibuat untuk dapat menerima masukan berupa username dan password. Sistem memerlukan identitas pengguna untuk dapat menentukan respon selanjutnya, mengingat adanya perbedaan hak akses menu antara administrator pusat dan administrator daerah. Untuk 
masuk ke dalam sistem informasi perpustakaan pusat dan daerah, maka diperlukan proses autentifikasi akun yang direpresentasikan dalam form Login. Aktor diminta untuk memasukkan input berupa username dan password. Sistem akan melakukan validasi pada masing-masing input. Tahap validasi ini berada pada lapisan Business Logic Layer. Jika sesuai dengan data pada tabel user maka sistem akan menampilkan pesan login berhasil dan akan diarahkan ke halaman administrator pusat dan administrator daerah. Lapisan ketiga, yaitu Communication Layer akan berperan pada tahap ini. Communication layer akan menentukan access right dari masing-masing aktor setelah aktor melakukan input data melalui form Login.

Perbedaan antarmuka sistem antara administrator pusat dengan administrator daerah terletak pada menu pengelolaan data buku. Menu Pengelolaan data buku terdiri dari View Data, Simpan, Edit, dan Delete. Untuk Administrator Pusat memiliki hak akses ke semua menu, sedangkan untuk Administrator Daerah hanya memiliki hak akses untuk View Data dan Simpan. Hal ini karena sistem telah melakukan disable pada kode program dari menu tersebut. Administrator daerah hanya memiliki hak akses untuk melakukan input data buku dan cari data buku perpustakaan.User Anggota tidak perlu melakukan proses Login. Anggota memiliki hak akses untuk melihat data buku perpustakaan melalui menu Cari Buku. Hal ini sesuai dengan perancangan awal sistem dimana terdapat dua administrator yang memiliki hak akses yang berbeda. Sistem ini dapat diakses oleh administrator pusat dan daerah sehingga data perpustakaan yang tersedia dapat diakses secara terintegrasi.

Menu Data Administrator merupakan representasi dari tabel user. Tabel ini menampilkan data administrator daerah dan administrator pusat.. Menu ini hanya dapat diakses oleh administrator pusat. Administrator pusat berhak untuk menambahkan data administrator daerah baru ke dalam sistem dengan menekan tombol 'Menambah Administrator Daerah Baru'. Pada kolom Alat terdapat menu Edit dan Delete untuk mengubah dan menghapus data administrator.

Untuk menambah data administrator, administrator pusat memasukkan data-data administrator yaitu password, nama, alamat, email, nomor handphone, dan level. Kemudian tekan tombol 'Simpan' maka data akan tersimpan pada tabel User. Untuk menu Edit data administrator, administrator pusat mengisi data baru administrator kemudian tekan tombol Simpan, maka data di tabel User akan ter-update. Ketika akan menghapus data administrator dengan tombol 'Delete', sistem akan mengkonfirmasi apakah ingin menghapus data administrator dengan username yang dipilih. Jika menekan 'ya' maka data administrator akan terhapus dari tabel User.

Menu Data Anggota Perpustakaan digunakan sebagai representasi dari tabel anggota. Tabel anggota ini berisi data anggota perpustakaan yang sudah melakukan registrasi melalui sistem perpustakaan. Anggota yang sudah terdaftar di sistem ini dapat melakukan transaksi peminjaman buku. Menu ini hanya dapat diakses oleh administrator pusat. Administrator pusat berhak melakukan edit data dan hapus data anggota. Untuk penambahan anggota baru perpustakaan, anggota dapat melakukan sendiri proses registrasi ke dalam sistem pada halaman utama sistem.

Menu Transaksi hanya dapat diakses oleh administrator pusat. Administrator pusat melakukan input data peminjaman melalui menu Input Transaksi. Dalam form input transaksi administrator pusat melakukan input data berupa judul buku, id buku yang dipinjam, nama peminjam, id peminjam, tanggal pinjam, tanggal kembali, status, dan keterangan.

Halaman data buku berisi data dari tabel bibliography. Untuk melihat data buku secara lengkap dapat menggunakan link Lihat Data pada kolom Tindakan. Pada halaman Lihat Data akan tertampil data buku secara lengkap. Untuk Administrator pusat akan terdapat menu Edit dan Delete untuk melakukan edit data dan menghapus data buku dari tabel bibliography.

\subsection{Pengujian Sistem}

Pengujian perangkat lunak adalah elemen kritis dari jaminan kualitas perangkat lunak dan merepresentasikan kajian pokok dari spesifikasi, desain dan pengkodean (Fatkhurrokhman, 2014:1). Oleh karena itu, tahapan pengujian pada sebuah sistem informasi menjadi sangat 
penting dilakukan. Pengujian sistem informasi perpustakaan pusat dan daerah dilakukan untuk mengukur aspek usability dan portability. Pengujian sistem dilakukan secara objektif dimana sistem diuji langsung ke lapangan dengan membuat kuesioner yang ditujukan kepada pengguna dari sistem informasi perpustakaan pusat dan daerah terhadap sistem yang telah dibangun. Sampel yang diambil sebanyak delapan orang yang merupakan calon pengguna aplikasi ini. Responden berasal dari masing-masing balai Kominfo yang berjumlah delapan balai. Tiap-tiap balai diambil sample satu orang untuk melakukan simulasi pengujian sistem. Sample dari pengujian ini adalah pustakawan dari perpustakaan pusat dan perpustakaan balai daerah.

Aspek portability didefinisikan sebagai aspek yang berkaitan dengan usaha yang diperlukan untuk dapat mentransfer sebuah program dari sebuah lingkungan perangkat keras atau lunak tertentu ke lingkaran yang lain (McCall, 1977). Pengujian aspek portability ini dilakukan dengan menjalankan sistem pada browser berbasis desktop. Hasil yang diharapkan adalah sistem kompatibel dengan beberapa browser terbaru. Hal ini dibuktikan dengan hasil pengujian (Tabel 1) bahwa sistem dapat diakses di beberapa browser seperti Mozilla Firefox, Internet Explorer, Opera dan Google Chrome tanpa terdapat pesan error.

Tabel 1. Hasil Pengujian Variabel Portability

\begin{tabular}{lll}
\hline No & Browser & Hasil \\
\hline 1 & Mozilla Firefox & Tidak ditemukan error \\
\hline 2 & Internet Explorer & Tidak ditemukan error \\
\hline 3 & Google Chrome & Tidak ditemukan error \\
\hline 4 & Opera & Tidak ditemukan error \\
\hline
\end{tabular}

Usability adalah atribut kualitas yang digunakan untuk menilai seberapa mudah tampilan antar muka suatu produk untuk digunakan. Pengujian ini menggunakan kuesioner Computer System Usability Questionnaire (CSUQ) yang dikembangkan oleh IBM untuk standar pengukuran usability perangkat lunak (Lewis, 1993).

Kuesioner ini terdiri dari sembilan belas pertanyaan dengan menggunakan empat pilihan jawaban yang mewakili dari tujuan akhir yang dicapai dalam pembangunan sistem informasi perpustakaan pusat dan daerah. Analisis usability dilakukan dengan menghitung hasil yang diperoleh dari kuesioner Lewis. Perhitungan untuk pengujian sistem dilakukan dengan beberapa tahapan. Tahap pertama adalah dengan menghitung jumlah responden pada masingmasing jawaban dari tiap-tiap pertanyaan. Terdapat empat pilihan jawaban yang masing-masing bernilai satu sampai empat. Perhitungan hasil kuesioner dilakukan dengan cara menghitung total dari masing-masing pertanyaan sesuai dengan hasil responden kemudian dikalikan dengan nilai masing-masing jawaban. Persamaan 1 digunakan untuk menghitung total nilai kuesioner, dimana $\mathrm{k}$ adalah total jawaban responden dan a adalah bobot nilai. Dari Persamaan 1 dapat diketahui bahwa total nilai hasil kuesioner adalah 446. Kemudian dilakukan perhitungan interval kelas dengan Persamaan 2, dimana $\mathrm{n}$ adalah jumlah responden. Hasil dari perhitungan Persamaan 2 adalah $\mathrm{K}=1+3,3(0,903)=3,9 \approx 4$. Maka interval kelas yang digunakan untuk kategori nilai sebanyak empat kelas. Kategori keempat kelas ini adalah Tidak Baik, Cukup, Baik, dan Sangat Baik.

Total nilai kuesioner $=k * a$

$K=1+3,3 \log n$

Kemudian dilakukan perhitungan nilai maksimal dengan asumsi semua menjawab empat dan nilai minimal dengan asumsi semua menjawab satu dengan menggunakan Persamaan 3 dan Persamaan 4, dimana $\mathrm{n}$ adalah jumlah responden dan a adalah jumlah pertanyaan.

nilai maksimal $=n * a * 4$

nilai minimal $=n * a * 1$ 
Dari Persamaan 3 dan Persamaan 4 maka didapatkan nilai maksimal adalah 608 dan nilai minimal adalah 152. Nilai ini digunakan sebagai batas maksimal dan nimimal pada interval kelas. Berdasarkan nilai maksimal dan nilai minimal dilakukan perhitungan rentang kelas dan panjang kelas dengan menggunakan Persamaan 5 dan Persamaan 6. Dari Persamaan 5 dan Persamaan 6 didapatkan nilai rentang kelas adalah 456 dan panjang kelas adalah 114,25. Dari nilai tersebut dilakukan penggolongan interval nilai seperti pada Tabel 2.

$$
\begin{aligned}
& \text { Rentang kelas }=(\text { nilai maksimal }- \text { nilai minimal })+1 \\
& \text { Panjang kelas }=\frac{\text { rentang kelas }}{k}
\end{aligned}
$$

Tabel 2. Pengelompokkan Interval

\begin{tabular}{ll}
\hline Interval Nilai & Kategori \\
\hline $152-266,25$ & Tidak baik \\
\hline $267.25-381,5$ & Cukup \\
\hline $382,5-496,75$ & Baik \\
\hline $497,75-612$ & Sangat baik \\
\hline
\end{tabular}

Dapat dilihat pada Tabel 2 bahwa nilai perhitungan 446 berada pada rentang 382,5496,75 dengan kategori "Baik" sehingga dapat dikatakan sistem informasi yang dikembangkan memiliki kualitas yang baik. Hal ini dapat dilihat dari atribut pengujian sistem yang dikembangkan dalam kuesioner. Secara keseluruhan, 87,5\% responden merasa puas dengan kinerja sistem informasi perpustakaan pusat dan daerah. Dengan adanya sistem ini, responden dapat melakukan pengelolaan data buku perpustakaan dengan cepat. Hal ini didukung dengan kemudahan informasi yang diberikan oleh sistem ini. Tata letak informasi pada sistem ini juga mudah dipahami oleh $87,5 \%$ responden

\section{Kesimpulan}

Pada penelitian perancangan prototype sistem informasi perpustakaan pusat dan daaerah menghasilkan beberapa kesimpulan sebagai berikut: (1) Prototype sistem informasi perpustakaan pusat dan daerah dapat berjalan dengan baik pada beberapa browser. Hal ini ditunjukkan pada pengujian aspek portability dimana sistem informasi perpustakaan pusat dan daerah dapat berjalan pada browser Mozila Firefox, Internet Explorer, Google Chrome dan Opera tanpa ada pesan error. 2) Hasil pengujian usability menunjukkan bahwa sistem informasi yang dikembangkan termasuk dalam kategori Baik sehingga sistem ini layak untuk digunakan dalam pengelolaan perpustakaan. Hal ini ditunjukkan dengan mengelompokkan total nilai kuesioner ke dalam pengelompokkan interval dan berada pada kategori baik dengan interval nilai 382,5-496,75. (3) Fungsi utama dari prototype ini adalah untuk membantu pengelolaan buku dari perpustakaan pusat dan perpustakaan daerah. Hal ini dapat ditunjukkan dengan adanya dua administrator yang dapat mengakses sistem informasi ini sehingga aktifitas sistem dapat diakses oleh administrator daerah secara terintegrasi. Pengujian aspek usability menunjukkan bahwa, 87,5\% responden merasa puas dengan kinerja sistem informasi perpustakaan pusat dan daerah. Dengan adanya sistem ini, responden dapat melakukan pengelolaan data buku perpustakaan dengan cepat.

\section{Referensi}

Cheah, R.S.S., Lee, F. B.S. \& Lim, R.L. 1993. Implementation of OSI Application Layer Using ISO Development Environment. Proceedings of IEEE Singapore International Conference on, 1, 28-33.

Chen, Z. 2011. The Research Of Software Development Supporting Environment Based On $U M L$. Electronic and Mechanical Engineering and Information Technology (EMEIT), 2011 International Conference on, 1, 98-101.

DeLone, W. D. 2013. The DeLone and McLean Model of Information Systems Success: A TenYear Update. Journal of Management Information System / Spring 2013, Vol. 19(4), 9- 
30.

Dwiyanto, A. R. 2007. Peran Perpustakaan Nasional RI dalam Pengembangan Literasi Informasi sebagai Amanat Konstitusi. Majalah Visi Pustaka Vol. 9 No.3.

Fatkhurrokhman, M. 2014. Analisis Pengujian Sistem Informasi Akademik STMIK El Rahma Yogyakarta menggunakan International Organization for Standardization (ISO 9126). (Online), (http://www.academia.edu/7335602/Analisis_Pengujian_Sistem_Informasi_ Akademik_STMIK_El_Rahma_Yogyakarta_menggunakan_International_Organization _for_Standardization_ISO_9126, diakses 31 December, 2014).

Lewis, J. 1993. IBM Computer Usability Satisfaction Questionnaires: Psychomotric Evaluation and Instructions for Use. Boca, Raton: IBM Corporation.

Li, Y., Zheng, H., Yang, T., \& Liu, Z. 2012. Design and Implementation of a Library Management System Based on the Web Service. Multimedia Information Networking and Security (MINES), 433,436.

McCall, J. A., Richards, P. K., \& Walters, G. F. 1977. Factors in Software Quality, Volumes I, II, and III, US Rome Air Development Center Reports NTIS AD/A-049 014. NTIS AD/A-049 015 and NTIS AD/A-049 016, NY: US Department of Commerce.

Mei, R., \& Guang-Quan, Z. 2007. Design and Implement of Library System Based on Software Architecture and UML. Computer Science, 224-227.

Naji, H., \& Liu, H. X. 2010. Research and Design of Library Information System Based on Three Layers Architecture. Information Engineering and Computer Science (ICIECS), 1-3.

Ramli, P. D., Rianto, D. Y. \& Meiningsih, S. 2013. Buku Putih TIK Kominfo 2013. Jakarta: Badan Litbang SDM Kominfo.

Suhartika, I. P. 2004. Implementasi Teknologi Informasi Sebagai Usaha Peningkatan Mutu Pelayanan Perpustakaan. Visi Pustaka, 6.

Supandi, D. 2012. Model Arsitektur Jaringan (OSI Layer dan TCP/IP Layer). (Online), (https://denihsupandijakstik.wordpress.com/2012/10/22/model-arsitektur-jaringan-osilayer-dan-tcpip-layer/, diakses 23 April 2014).

Yanqing, R. \& Yongming, W. 2010. Development of Web-Based University Library Teaching Reference Information System. Education Technology and Computer Science (ETCS), $2,488-491$.

Zimmermann, H. 1980. OSI Reference Model-The ISO Model of Architecture for Open Systems Interconnection. IEEE Transactions on Communications, 28(4), 425-432. 